\title{
Using Reclaimed Water to Irrigate Turfgrass - Lessons Learned from Research with Nitrogen ${ }^{1}$
}

\author{
George Hochmuth, Jinghua Fan, Jason Kruse, and Jerry Sartain²
}

Municipal wastes are treated at a wastewater treatment facility to produce biosolids and reclaimed water. Reclaimed water treated by filtration and chlorination is safe to use for designated purposes, such as residential landscape irrigation. Florida began using reclaimed water in 1966, and it is a leading state for using reclaimed water. Approximately 660 million gallons of reclaimed water are used every day in Florida, and the state encourages using reclaimed water as an alternative water source to reduce the pressure on potable water supplies.

This publication summarizes the results of a recent research project and provides research-based information for improving nutrient and water management with reclaimed water irrigation of turfgrass. The research described below was supported by funds from the St. Johns River Water Management District and from the Florida Department of Environmental Protection. The information is intended for use by county agents to prepare educational materials about the use of reclaimed water for irrigation of landscapes.

Turfgrass in the urban landscape requires appropriate amounts of water and nutrients for optimal growth and health. Residents can benefit from reclaimed water because it satisfies turfgrass irrigation needs for maintaining growth. Reclaimed water also contains nutrients, such as nitrogen $(\mathrm{N})$, phosphorus $(\mathrm{P})$, and potassium $(\mathrm{K})$ that support healthy plant growth. Nutrients in reclaimed water originated largely from human wastes that were treated at the wastewater facility. When reclaimed water is applied to plants, it can offset some of the plants' nutritional needs that would have otherwise been supplied as fertilizer.

We conducted a research project to answer several questions about using reclaimed water for turfgrass irrigation. We considered the following questions:

- Can turfgrass utilize the $\mathrm{N}$ in reclaimed water for growth?

- At what concentration of $\mathrm{N}$ in reclaimed water can turfgrass $\mathrm{N}$ be satisfied?

- How does management of reclaimed water irrigation affect leaching loss of $\mathrm{N}$ ?

\section{UF/IFAS Research with Reclaimed Water}

The research was conducted in the Envirotron glasshouse at the University of Florida using reclaimed water from the campus wastewater treatment facility. The research was conducted from July 2011 through August 2012. 'Floratam' St. Augustinegrass (Stenotaphrum secundatum) and 'Empire' Zoysiagrass (Zoysia japonica) turfgrasses were grown from sod supplied by a commercial sod farm and planted on sand media in small ( 38 by $30 \mathrm{~cm} ; 15$ by 12 inches) plastic kitchen tubs (Figure 1). The tubs were fitted with a drainage port at one end to collect leachate.

1. This document is SL389, one of a series of the Soil and Water Science Department, UF/IFAS Extension. Original publication date November 2013. Visit the EDIS website at http://edis.ifas.ufl.edu.

2. George Hochmuth, professor, Soil and Water Science Department; Jinghua Fan, post-doctoral associate, Soil and Water Science Department; Jason Kruse, assistant professor, Environmental Horticulture Department; and Jerry Sartain, professor, Soil and Water Science Department; UF/IFAS Extension, Gainesville, FL 32611.

The Institute of Food and Agricultural Sciences (IFAS) is an Equal Opportunity Institution authorized to provide research, educational information and other services only to individuals and institutions that function with non-discrimination with respect to race, creed, color, religion, age, disability, sex, sexual orientation, marital status, national origin, political opinions or affiliations. For more information on obtaining other UF/IFAS Extension publications, contact your county's UF/IFAS Extension office. 
Reclaimed water was used to formulate various irrigation solutions. The irrigation amount was $300 \mathrm{ml}$ per tub per application daily; this is equivalent to $1.5 \mathrm{~cm}(0.6 \mathrm{inch})$ per week if irrigation occurs daily. The recommended rate of irrigation in northern Florida is about $2 \mathrm{~cm}$ per week. The application frequency was evaluated every three days based on turf growth and weather. The turfgrass was irrigated once daily in the period from April through November. The irrigation frequency was changed to four days per week in December and March, and three days per week in January and February.

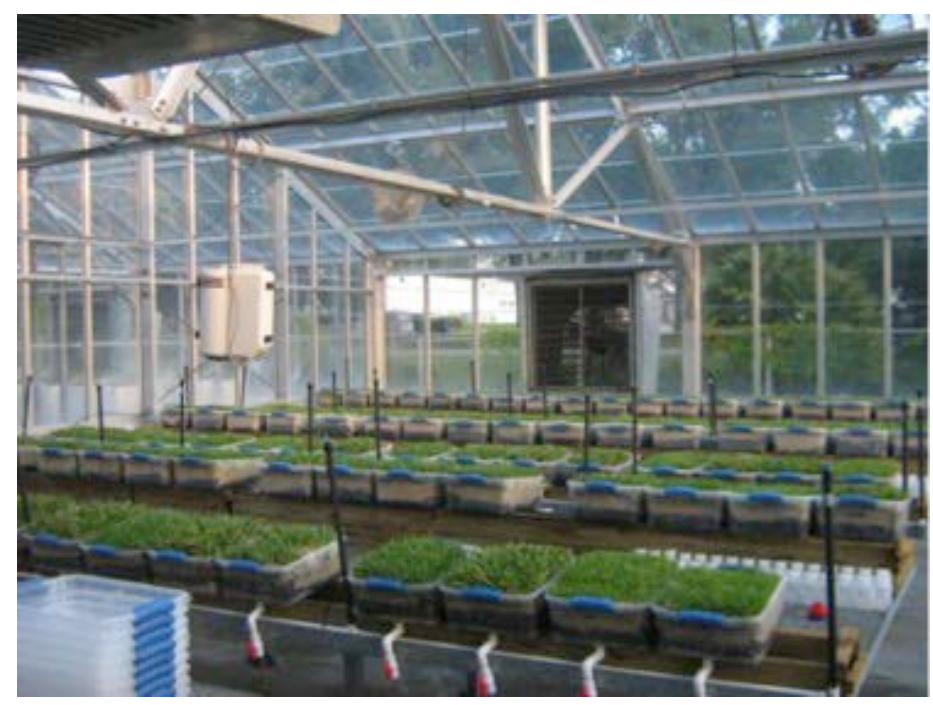

Figure 1. Overview of greenhouse set-up, showing the growing tubs with established sod and the drains for collecting leachate.

Credits: Dr. Jinghua Fan

All irrigation treatments were hand applied using measured volumes of water poured from a graduated beaker. The turfgrass was hand clipped to measure biomass production on several occasions throughout the year. Leachate was collected from the tubs and analyzed for nitrate- $\mathrm{N}$ concentrations at the UF/IFAS Analytical Research Lab. At the end of the research period, sod was harvested from the tubs to measure the root, verdure, and thatch production, as well as their nutrient contents to facilitate calculation of a nutrient mass budget for $\mathrm{N}$.

\section{Growth Response to Nitrogen Concentration in Reclaimed Water}

The concentrations of the various nitrogen $(\mathrm{N})$ species (total-N, nitrate- $\mathrm{N}$, and ammonium-N) in the reclaimed water on campus varied during the year (Figure 2). Most of the $\mathrm{N}$ in the reclaimed water was in the form of nitrate- $\mathrm{N}$. We studied a range of $\mathrm{N}$ concentrations in the irrigation water of $0,3,5,9$, and 13 parts per million (ppm). All irrigation solutions had the base level of reclaimed water at $3 \mathrm{ppm}$ total $\mathrm{N}$, and then $\mathrm{N}$ from ammonium nitrate was added to derive the solutions with the higher $\mathrm{N}$ concentrations. Ammonium nitrate was chosen for this research because it supplies a mixture of nitrate- $\mathrm{N}$ and ammonium$\mathrm{N}$. A treatment comprising the UF/IFAS recommendations for $\mathrm{N}$ (dry ammonium nitrate at $4 \mathrm{lbs}$ per 1000 square feet per year of $\mathrm{N}$ ) was used as a comparison treatment. The dry fertilizer was applied in 12 (monthly) portions.

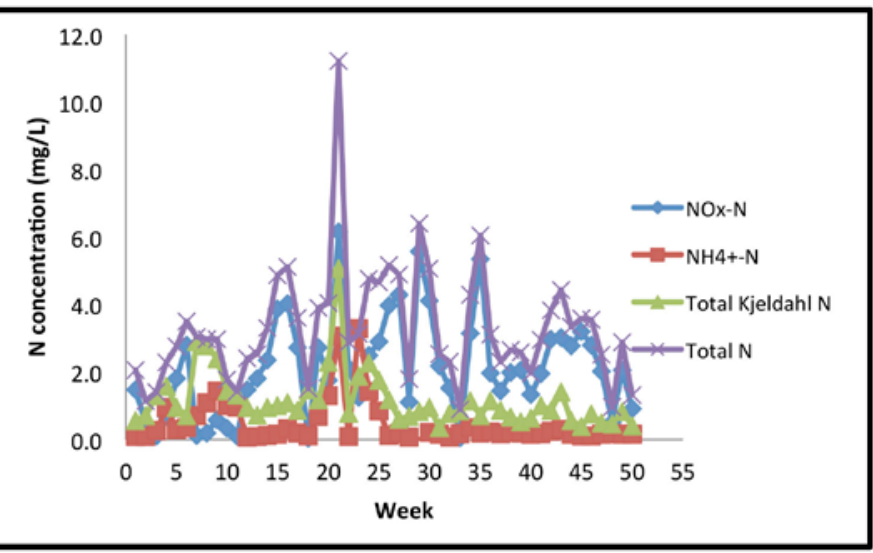

Figure 2. Concentrations of $\mathrm{N}$ species in the University of Florida reclaimed water from July 2011 (week 0) through August 2012 (week 50). An average of $3.0 \mathrm{mg} / \mathrm{L}$ total $\mathrm{N}$ was used to represent the base level of $\mathrm{N}$ supplied from the waste water treatment facility.

Credits: Dr. Jinghua Fan

Turfgrass clippings biomass increased as $\mathrm{N}$ concentration in the reclaimed water increased until 9 ppm (Figure 3). Both turfgrass types responded similarly to $\mathrm{N}$ concentration in the reclaimed water. Irrigating with reclaimed water containing 9 ppm total $\mathrm{N}$ resulted in turfgrass growth rates similar to those achieved using the standard UF/IFAS fertilization recommendation. The reclaimed water from the campus wastewater facility at $3 \mathrm{ppm} \mathrm{N}$ did not supply enough $\mathrm{N}$ to sustain turfgrass growth. However, turfgrass irrigated with water with $3 \mathrm{ppm} \mathrm{N}$ grew better than the turfgrass irrigated with tap water $(0 \mathrm{ppm} \mathrm{N})$. These results answer the first and second research questions; turfgrass does respond to $\mathrm{N}$ in reclaimed water. Irrigation with reclaimed water with $\mathrm{N}$ concentration near 9 ppm will satisfy turfgrass $\mathrm{N}$ needs comparable to fertilizer.

Differences in turfgrass growth were caused by differences in $\mathrm{N}$ uptake by the plants (Figure 4). The turfgrass $\mathrm{N}$ uptake was maximized with irrigation water containing 9 ppm total N. Combined with the dry-matter results, these results show that turfgrass responded to $\mathrm{N}$ in reclaimed water. But the minimum $\mathrm{N}$ concentration (near $3 \mathrm{ppm}$ from the UF/ IFAS facility) is not enough to sustain adequate turfgrass growth. While turfgrass can benefit when $\mathrm{N}$ concentration 
exceeds the 3 ppm level in reclaimed water, the researchers' results indicated that reclaimed water with near 9 ppm total $\mathrm{N}$ can be effectively used to reduce most of the need for fertilizer in turfgrass.

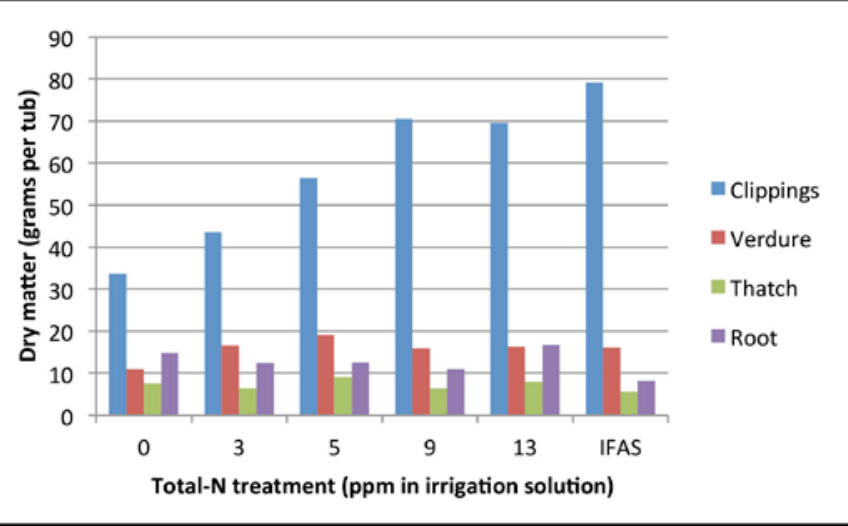

Figure 3. This table shows dry matter accumulation (averaged over two turfgrass types) in response to $\mathrm{N}$ in the irrigation solution. The amount of dry matter from clippings increased as the $\mathrm{N}$ increased from 0 to $9 \mathrm{mg} / \mathrm{L}$, and then it leveled off. $\mathrm{N}$ concentration did not affect the final root, thatch, or verdure dry matter.

Credits: Dr. Jinghua Fan

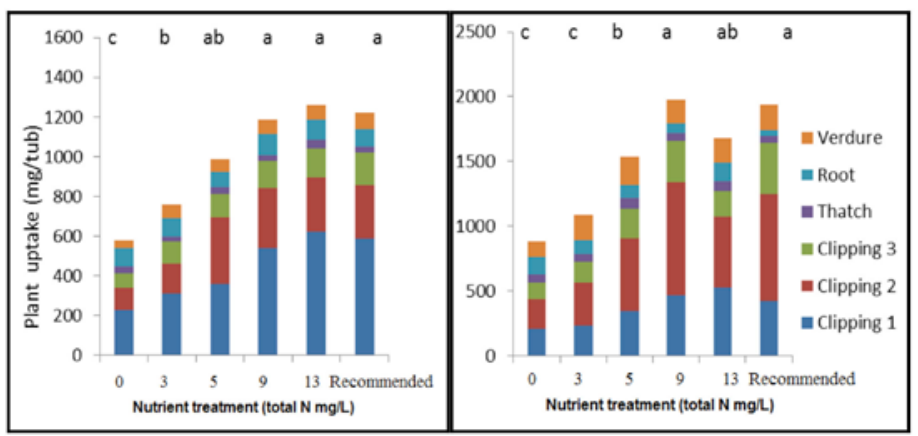

Figure 4. Plant N uptake of 'Floratam' St. Augustinegrass on the left and 'Empire' Zoysiagrass on the right. Researchers harvested clippings three times during the year - Clippings 1-3 in the chart. (Letters across the top indicate the statistical significance of the column height. Columns, or treatment means for total $\mathrm{N}$ uptake, with the same letter are not significantly different from each other.) Credits: Dr. Jinghua Fan

Currently, wastewater treatment facilities are being encouraged to reduce the concentrations of nutrients in the resulting treated water, but the technologies to reduce the $\mathrm{N}$ concentration are costly. Our research results indicate the option of not needing the complete removal of $\mathrm{N}$, and leaving some $\mathrm{N}$ in reclaimed water could make it a valuable product as a potential offset to fertilizer. Wastewater utilities supplying treated water to residential areas could show the homeowner the benefits of using treated wastewater for irrigation and show the potential for reducing fertilizer purchases.
The recommended irrigation rate in northern Florida is about $2 \mathrm{~cm}$ per week, and the study results showed the greenhouse studies were likely to be representative of outdoor turfgrass situations. These results should nevertheless be confirmed in larger outdoor experiments under typical growing and irrigation conditions where mixtures from $\mathrm{N}$ from reclaimed water and $\mathrm{N}$ from fertilizer are evaluated.

\section{Nitrogen-leaching Responses to Irrigation Management}

One of the concerns with irrigation with reclaimed water is the potential for leaching of $\mathrm{N}$ that comes with the reclaimed water or the $\mathrm{N}$ that was previously applied as fertilizer, if the irrigation is not managed properly. The concern for leaching of nitrate- $\mathrm{N}$ is important because leached $\mathrm{N}$ represents a pollution threat to water bodies and an economic loss in terms of lost fertilizer. In a separate experiment, we studied a range of irrigation rates using reclaimed water for the effects on St. Augustinegrass growth and on leaching of $\mathrm{N}$. The turfgrass grew faster when the irrigation rate increased from $1 \mathrm{~cm}$ per week to $2 \mathrm{~cm}$ per week (Figure 5). Growth then leveled off and was similar as irrigation rate changed from 2 to $4 \mathrm{~cm}$ per week $(2.54$ $\mathrm{cm}$ equals $1 \mathrm{inch}$ ). Typical recommended irrigation rate in northern Florida would be near $2 \mathrm{~cm}$ per week. These results show that our studies in the greenhouse were representative of outdoor turfgrass situations.

Irrigation rates affected the leaching of $\mathrm{N}$ (Table 1). There was no leaching of $\mathrm{N}$ until the rate of $3 \mathrm{~cm}$ per week.

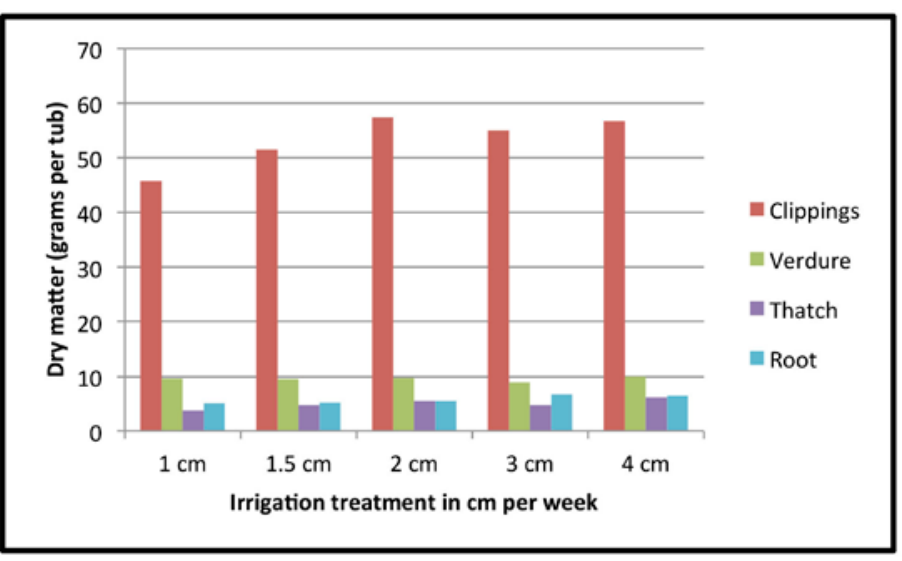

Figure 5. Dry matter accumulation of 'Floratam'St. Augustinegrass turfgrass (averaged over two water sources). Dry matter increased as irrigation level increased from 1 to $2 \mathrm{~cm}$ per week, and then it leveled off. The final dry matter of verdure, thatch, and root was not affected by irrigation level.

Credits: Dr. Jinghua Fan

The following results can be observed in Table 1 . 
- Leaching did not occur until the irrigation rate increased to more than $2 \mathrm{~cm}$ per week, which is about the recommended irrigation rate for summer in northern Florida.

- As the irrigation rate increased from 3 to $4 \mathrm{~cm}$ per week, leaching of $\mathrm{N}$ increased.

- As the fertilizer rate increased from 0.5 to 1 times the recommended rate, leaching of $\mathrm{N}$ also increased.

- Leached $\mathrm{N}$ was never greater than $6 \%$ of the total $\mathrm{N}$ inputs.

- The $\mathrm{N}$ mass balance was nearly always positive, meaning not all $\mathrm{N}$ applied was accounted for in the leachate plus plant uptake.

\section{Overall Lessons Learned from this} Research

- As long as the $\mathrm{N}$ concentration in the water is high enough to supply adequate $\mathrm{N}$ for turfgrass growth, reclaimed water can be a significant source of $\mathrm{N}$ for turfgrass growth. In our studies, the $\mathrm{N}$ concentration in the reclaimed water needed to be $9 \mathrm{ppm}$ total $\mathrm{N}$ to supply most of the required $\mathrm{N}$. As wastewater utilities are asked to reduce the concentration of $\mathrm{N}$ towards zero, concentrations on the order of $9 \mathrm{ppm}$ total $\mathrm{N}$ may become less common.

- Depending on the activities and management of the treatment process at the wastewater facility, the $\mathrm{N}$ concentration in the reclaimed water can vary during the year. This needs to be taken into account when calculating how much $\mathrm{N}$ can be supplied from the reclaimed water.

- Leaching of $\mathrm{N}$ occurred only after the irrigation rate increased to more than $2 \mathrm{~cm}$ per week.

- Even though leaching occurred, the amount of $\mathrm{N}$ leached was never more than $6 \%$ of the total $\mathrm{N}$ applied from reclaimed water and fertilizer. Turfgrass is efficient at removing $\mathrm{N}$ from the soil solution. 
Table 1. N inputs and outputs and mass balance with irrigation level

\begin{tabular}{|c|c|c|c|c|c|c|}
\hline \multirow[b]{2}{*}{ Treatment $^{z}$} & \multicolumn{2}{|c|}{ N output } & \multicolumn{3}{|c|}{ N input } & \multirow[t]{2}{*}{ N mass balance } \\
\hline & Leaching loss & Plant uptake & Fertilizer & RW source & Total & \\
\hline & \multicolumn{6}{|c|}{ 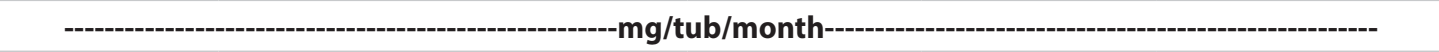 } \\
\hline $1.0 \mathrm{~cm}$ half rate & 0 & 68.9 & 113.5 & 16.2 & 129.7 & 60.7 \\
\hline $1.0 \mathrm{~cm}$ full rate & 0 & 103.6 & 227.0 & 16.2 & 243.2 & 139.6 \\
\hline $1.5 \mathrm{~cm}$ half rate & 0 & 136.8 & 113.5 & 24.3 & 137.8 & 1.0 \\
\hline $1.5 \mathrm{~cm}$ full rate & 0 & 210.8 & 227.0 & 24.3 & 251.3 & 40.5 \\
\hline $2.0 \mathrm{~cm}$ half rate & 0 & 150.2 & 113.5 & 32.3 & 145.8 & -4.3 \\
\hline $2.0 \mathrm{~cm}$ full rate & 0 & 137.8 & 227.0 & 32.3 & 259.3 & 121.5 \\
\hline $3.0 \mathrm{~cm}$ half rate & 7.6 & 114.2 & 113.5 & 48.5 & 162.0 & 40.2 \\
\hline $3.0 \mathrm{~cm}$ full rate & 8.2 & 159.7 & 227.0 & 48.5 & 275.5 & 107.5 \\
\hline $4.0 \mathrm{~cm}$ half rate & 11.8 & 125.9 & 113.5 & 64.7 & 178.2 & 40.5 \\
\hline $4.0 \mathrm{~cm}$ full rate & 15.5 & 133.8 & 227.0 & 64.7 & 291.7 & 142.4 \\
\hline
\end{tabular}

